\title{
Toxicological studies of aqueous and ethanol leaf extract of Spondias purpurea (red plum) in rats
}

\author{
T. Y. Gara ${ }^{1 *}$ (D, A. I. Daniel ${ }^{1}$, F. M. Muhammad ${ }^{1}$ and H. H. Ndayako²
}

\begin{abstract}
Background: Spondias purpurea is a flowering plant of the cashew family commonly found in South Western Nigeria. The plant is used in folk medicine for treatment of gastric disorders and diarrhoea. The purpose of the study was to investigate the haematological and histopathological effects of aqueous and ethanol leaf extract of $S$. purpurea (red plum) in rats.

Methods: Female wistar rats weighing $(121.5 \pm 30.41 \mathrm{~g})$ were administered 500, 1000 and $1500 \mathrm{mg} / \mathrm{kg}$ body weight of aqueous and ethanol extracts of S. purpurea leaf (orally) daily for 14 days, while the control group was administered $0.5 \mathrm{ml}$ of normal saline (vehicle). At the end of the study, the rats were euthanized; blood samples were collected for haematological parameters. The liver, kidney and spleen were harvested from the rats for photomicrographic examination.

Result: The result of the acute toxicity test revealed no death with dose up to $5000 \mathrm{mg} / \mathrm{kg}$ body weight. The administration of the extracts showed no significant difference $(p>0.05)$ in the hematologic parameters of the animals. The liver sections showed congestion, mononuclear infiltration, widened sinusoidal space and congestions with hemosiderin. Similar changes were observed in the kidney showing slight necrosis of renal tubular epithelium, widened Bowman's space, and collapsed renal tubules and adhesion of the parietal layer of glomerulus to the Bowman's space. The spleen showed congestion, lymphocyte proliferation at the germinal centre.

Conclusions: The result of this study showed that the alterations observed in the organs intensified with increase in the doses of the extracts administered. It can be inferred that the prolonged consumption of S. purpurea leaf maybe associated with significant tissue damage of some vital organs.
\end{abstract}

Keywords: Spondias purpurea, Hematology, Histopathology, Acute toxicity

\section{Introduction}

Natural plant products are essential sources of food and the backbone of medicines attributable to the presence of bioactive agents which serve as materials for development of synthetic chemical compounds utilized to meet basic human needs $[1,2]$. Plants play a significant role in the treatment of diseases especially in communities where there are strong beliefs in herbal remedies,

\footnotetext{
* Correspondence: t.gara@futminna.edu.ng

${ }^{1}$ Department of Biochemistry, Federal University of Technology, Minna, Nigeria

Full list of author information is available at the end of the article
}

insufficient funds or no easy access to health care system. The uniqueness of natural drug substances is their therapeutic roles in disease conditions regulating numerous metabolic processes owing to the presence of bioactive compounds. Nevertheless, excessive consumption of some of these active compounds may lead to organ toxicity and affect several developmental stages of disease $[1,3]$.

Blood is an indicator commonly used to determine the health status of an individual because of its ability to deliver nutrients, oxygen to the cells, alongside transports metabolic waste out of the cells in the body. Blood and

\section{SpringerOpen}

(๑) The Author(s). 2021 Open Access This article is licensed under a Creative Commons Attribution 4.0 International License, which permits use, sharing, adaptation, distribution and reproduction in any medium or format, as long as you give appropriate credit to the original author(s) and the source, provide a link to the Creative Commons licence, and indicate if changes were made. The images or other third party material in this article are included in the article's Creative Commons licence, unless indicated otherwise in a credit line to the material. If material is not included in the article's Creative Commons licence and your intended use is not permitted by statutory regulation or exceeds the permitted use, you will need to obtain permission directly from the copyright holder. To view a copy of this licence, visit http://creativecommons.org/licenses/by/4.0/. 
tissue disorders caused by the toxic effect of ingested plants, can be evaluated by haematological and histopathological studies due to its reliability and sensitivity [4].

Spondias purpurea commonly known as red plum belongs to the genus Spondias, of the family Anacardiaceae, which comprises of more than 70 genera and over 600 species [5]. They are mainly trees and shrubs growing in tropical, subtropical and naturalized in countries like Nigeria and Philippines [6, 7]. In folk medicine, different parts of the plant are used to treat various diseases. The plant is reported to have antibacterial activities [8], the fruits are said to possess antioxidant potential and help prevent complications related to advanced glycation end products (AGEs) in diabetes mellitus [9]. The leaves have antiulcer properties [10]. In North Central Nigeria, a decoction of the leaves is used as diuretic and for inducing the expulsion of placenta in domestic animals [6]. Though plant based natural remedies are popularly acclaimed to be safe, there are indiscriminate uses of these plants coupled with their processing either through water or alcohol extractions of active compounds and so scientists advocate for proper toxicological studies to ensure safety in their use [1113]. Some cultures in Nigeria, believe that $S$. purpurea possess haematinic potentials and consume decoctions made from the leaves of the plant. Therefore, it is needful to evaluate the haematological and histopathological effects of S. purpurea leaves to substantiate the claim.

\section{Materials and methods}

\section{Collection and processing of plant materials}

Fresh leaves of S. purpurea were collected from Area F, in Zaria. The Plant was identified at the Department of Plant Biology Federal University of Technology Minna and the voucher specimen number was FUT/PLB/AN/ 003. The leaves were rinsed under running tap water, air dried at ambient temperature and grinded to powder form and stored in an air tight container prior to use.

The powdered plant materials were extracted in two solvent such as water and absolute ethanol. Hundred (100) grams of the powdered dried leaves were soaked in $400 \mathrm{ml}$ of solvent and stored at room temperature for $24 \mathrm{~h}$. The extracted solution was filtered through muslin cloth and the filtrate was evaporated to dryness over a water bath at $50{ }^{\circ} \mathrm{C}$.

\section{Experimental animals}

Female wistar rats weighing $(121.5 \pm 30.41 \mathrm{~g})$ were obtained from the animal house, Faculty of Pharmaceutical science, Ahmadu Bello University Zaria. They were housed in cages and allowed to acclimatize at room temperature for 2 weeks with free access to feed and water ad-libitum [14].

\section{Acute toxicity study}

Acute toxicity study was carried out by method described by Lorke, 1983 [15]. In the first phase, rats were divided into 6 groups of 3 rats each and administered with aqueous and ethanol extracts of $S$. purpurea leaf by gavage at doses 10, 100 and $1000 \mathrm{mg} / \mathrm{kg}$ body weight. All animals were observed for $24 \mathrm{~h}$. In the absence of death, the second phase was carried out. Rats were divided into 6 groups of one rat each and treated with the extracts at doses of 1600,2900 and $5000 \mathrm{mg} / \mathrm{kg}$ body weight. The animals were observed for $24 \mathrm{~h}$ for signs of toxicity, including death.

\section{Experimental design}

The rats were weighed and randomly assigned into seven groups of four rats each. They were orally administered at doses of 500,1000 and $1500 \mathrm{mg} / \mathrm{kg}$ of the extracts daily [16].

Group 1: served as normal control group and received $0.5 \mathrm{ml}$ of normal saline.

Group 2: received $500 \mathrm{mg} / \mathrm{kg}$ body weight of the aqueous extract.

Group 3: received $1000 \mathrm{mg} / \mathrm{kg}$ body weight of the aqueous extract.

Group 4: received $1500 \mathrm{mg} / \mathrm{kg}$ body weight of the aqueous extract.

Group 5: received $500 \mathrm{mg} / \mathrm{kg}$ body weight of the ethanol extract.

Group 6: received $1000 \mathrm{mg} / \mathrm{kg}$ body weight of the ethanol extract.

Group 7: received $1500 \mathrm{mg} / \mathrm{kg}$ body weight of the ethanol extract.

The extracts were orally administered daily for a period of 14 days. Twenty-four hours after the last administration, the animals were anaesthetized with phenobarbital and blood samples were collected from orbital plexus by means of heparinized capillary tubes. The animals were sacrificed, quickly dissected, relevant organs collected and fixed in $10 \%$ formal saline for histopathological studies.

\section{Determination of haematological parameters}

Packed cell volume (PCV) was determined using microhematocrit method, White Blood Cell (WBC) by hemocytometer method. The hemoglobin concentrations were calculated from PCV values. Differential White blood cell (WBC) count was determined by Giemsa stain method.

\section{Estimation of total plasma protein}

Total protein concentration was determined according to the method of Lowry et al. [17]. In an alkaline medium, protein reacts with the copper in the Biuret reagent leading to an increase in absorbance due to 
Table 1 Effect of aqueous extract of Spondias purpurea leaf on hematological parameters in rats

\begin{tabular}{|c|c|c|c|c|}
\hline arar & Control & $500 \mathrm{mg} / \mathrm{kg}$ & $1000 \mathrm{mg} / \mathrm{kg}$ & $1500 \mathrm{mg}$ \\
\hline $\mathrm{V}($ & $43.75 \pm 1.71^{a}$ & $41.75 \pm 1.71^{a}$ & $42.75 \pm 1.71^{a}$ & $41.25 \pm 3.40^{a}$ \\
\hline $\mathrm{Hb}(\mathrm{g} / \mathrm{dL})$ & $a$ & $a^{a}$ & $9^{a}$ & \\
\hline $\mathrm{BC}\left(\times 10^{9}\right)$ & $12.63 \pm 4.8^{\mathrm{a}}$ & $14.88 \pm 3.36^{a}$ & $19.13 \pm 8.37^{\mathrm{a}}$ & $16.78 \pm 7.58^{\mathrm{a}}$ \\
\hline (\%) & & 1 & $74^{\mathrm{a}}$ & 1 \\
\hline -ym (\%) & $77.75 \pm$ & $82.25 \pm 5.19^{a}$ & $83.50 \pm 3.87^{\mathrm{a}}$ & $81.00 \pm 5.48^{\mathrm{a}}$ \\
\hline ond & $1.25 \pm 0.96^{\mathrm{a}}$ & $0.75 \pm 0.96^{\mathrm{a}}$ & $0.75 \pm 0.96^{\mathrm{a}}$ & 0.2 \\
\hline os (\%) & $0.25 \pm 0.50^{a}$ & $1.00 \pm 0.82^{a}$ & $0.50 \pm 0.58^{a}$ & $0.00 \pm 0.00^{\mathrm{a}}$ \\
\hline
\end{tabular}

Values are mean \pm standard deviation for 4 rats per group. Values with same alphabet in the same row are not statistically different. PCV Packed cell volume, HB Haemoglobin, WBC White blood cell, Neu Neutrophils, Lym Lymphocytes, Mono Monocytes, Eos Eosinophils

formation of colored complex. Reagent $(2.5 \mathrm{ml})$ and 0.05 $\mathrm{ml}$ serum sample were mixed. It was then incubated at room temperature for $10 \mathrm{~min}$. The absorbance was read at $540 \mathrm{~nm}$ against reagent blank.

\section{Histopathological studies}

Histopathology slides were prepared by the method described by Aliyu et al., [18]. The extracted tissues (liver, kidney and spleen) were fixed in $10 \%$ normal saline for $72 \mathrm{~h}$ after which the tissues were sliced to a thickness of $2.1 \mathrm{~mm}$ each. These were dehydrated using alcohol of graded concentrations. They were further treated with paraffin wax and cast into blocks; sections of the tissues were cut on a microtome to $5 \mu \mathrm{m}$. these were later attached to a slide and dried. The samples slides were then stained in haematoxylin and eosin. The slides were then viewed on a photomicrograpic microscope to detect any damage.

\section{Statistical analysis}

The analysis was performed using the statistical package for social sciences (SPSS) for WINDOWS (version 21.0; SPSS Inc., Chicago). Results were subjected to analysis

Table 2 Effect of ethanolic extract of Spondias purpurea leaf on haematological parameters in rats

\begin{tabular}{lllll}
\hline Parameter & Control & $\mathbf{5 0 0} \mathbf{~} \mathbf{g} / \mathbf{k g}$ & $\mathbf{1 0 0 0} \mathbf{~} \mathbf{g} / \mathbf{k g}$ & $\mathbf{1 5 0 0} \mathbf{~} \mathbf{g} / \mathbf{k g}$ \\
\hline PCV (\%) & $43.75 \pm 1.71^{\mathrm{a}}$ & $43.50 \pm 1.91^{\mathrm{a}}$ & $41.00 \pm 0.82^{\mathrm{a}}$ & $45.00 \pm 3.92^{\mathrm{a}}$ \\
$\mathrm{Hb}(\mathrm{g} / \mathrm{dL})$ & $14.58 \pm 0.56^{\mathrm{a}}$ & $14.50 \pm 0.63^{\mathrm{a}}$ & $13.68 \pm 0.29^{\mathrm{a}}$ & $15.00 \pm 1.31^{\mathrm{a}}$ \\
WBC (×10\%/L) & $12.63 \pm 4.8^{\mathrm{a}}$ & $14.68 \pm 3.93^{\mathrm{a}}$ & $15.38 \pm 3.40^{\mathrm{a}}$ & $14.85 \pm 4.56^{\mathrm{a}}$ \\
Neu (\%) & $20.25 \pm 3.77^{\mathrm{a}}$ & $19.50 \pm 6.61^{\mathrm{a}}$ & $16.75 \pm 4.79^{\mathrm{a}}$ & $16.25 \pm 5.50^{\mathrm{a}}$ \\
Lym (\%) & $77.75 \pm 4.34^{\mathrm{a}}$ & $78.25 \pm 4.72^{\mathrm{a}}$ & $82.75 \pm 5.25^{\mathrm{a}}$ & $82.50 \pm 6.45^{\mathrm{a}}$ \\
Mono (\%) & $1.25 \pm 0.96^{\mathrm{a}}$ & $0.75 \pm 0.96^{\mathrm{a}}$ & $0.25 \pm 0.50^{\mathrm{a}}$ & $0.50 \pm 0.58^{\mathrm{a}}$ \\
Eos (\%) & $0.25 \pm 0.50^{\mathrm{a}}$ & $0.75 \pm 0.50^{\mathrm{a}}$ & $0.00 \pm 0.00^{\mathrm{a}}$ & $0.50 \pm 0.58^{\mathrm{a}}$
\end{tabular}

Values are mean \pm standard deviation for 4 rats per group. Values with same alphabet in the same row are not statistically different. PCV Packed cell volume, HB Haemoglobin, WBC White blood cell, Neu Neutrophils, Lym Lymphocytes, Mono Monocytes, Eos Eosinophils
Table 3 Effect of aqueous and ethanolic extract of Spondias purpurea leaf on total plasma proteins in rats

\begin{tabular}{lll}
\hline GROUPS & AQ TPP $(\mathbf{g} / \mathbf{d L})$ & ET TPP $(\mathbf{g} / \mathbf{d L})$ \\
\hline Control & $6.90 \pm 0.47^{\mathrm{a}}$ & $6.90 \pm 0.47^{\mathrm{a}}$ \\
$500 \mathrm{mg} / \mathrm{kg}$ & $7.00 \pm 0.16^{\mathrm{a}}$ & $6.80 \pm 0.36^{\mathrm{a}}$ \\
$1000 \mathrm{mg} / \mathrm{kg}$ & $7.03 \pm 0.24^{\mathrm{a}}$ & $6.98 \pm 0.32^{\mathrm{a}}$ \\
$1500 \mathrm{mg} / \mathrm{kg}$ & $7.33 \pm 0.71^{\mathrm{a}}$ & $7.13 \pm 0.38^{\mathrm{a}}$ \\
\hline
\end{tabular}

Values are mean \pm standard deviation for 4 rats per group. Values with same alphabet in the same column are not statistically different. AQ Aqueous, ET Ethanol, TPP Total plasma protein

of variance (ANOVA) to determine their level of significance. Data were expressed as the mean \pm standard deviation. Values were considered statistically significant at $p>0.05$.

\section{Result}

\section{Acute toxicity study}

The administration of aqueous and ethanol extracts at different doses of 10,100,1000,1600, 2900 and 5000 $\mathrm{mg} / \mathrm{kg}$ body weight for phase 1 and phase 2 studies for acute toxicity did not produce any mortality in the animals after $24 \mathrm{~h}$. However, there was occasional clustering of the animals at a corner of the cage and an increase in water in-take compared to the control group. This result indicates that the $\mathrm{LD}_{50}$ for aqueous and ethanol extracts of $S$. purpurea leaf was above $5000 \mathrm{mg} / \mathrm{kg}$.

\section{Hematological studies}

The results of the hematological parameters of aqueous and ethanol extracts are listed in Tables 1 and 2. There were no significant $(p>0.05)$ changes in PCV, Hb, WBC and TPP of rats treated with aqueous and ethanol extracts of $S$. purpurea leaf at the doses of 500, 1000 and $1500 \mathrm{mg} / \mathrm{kg}$ body weight when compared with the control group.

\section{Total plasma protein studies}

The total plasma protein of rats administered aqueous and ethanol extracts of $S$. purpurea leaf at the doses of 500,1000 and $1500 \mathrm{mg} / \mathrm{kg}$ body weight revealed no

Table 4 Histopathological result of rat's liver administered aqueous and ethanolic extract of Spondias purpurea leaf

\begin{tabular}{|c|c|c|c|c|c|c|c|}
\hline \multirow[t]{2}{*}{ Histopathological changes } & \multirow[t]{2}{*}{ C } & \multicolumn{3}{|c|}{$\begin{array}{l}A Q \text { extract }(\mathrm{mg} / \\
\mathrm{kg}) \\
5,001,0001500\end{array}$} & \multicolumn{3}{|c|}{$\begin{array}{l}\text { ET extract }(\mathrm{mg} / \\
\mathrm{kg}) \\
5,001,0001500\end{array}$} \\
\hline & & 1 & & 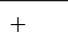 & & ( & 2 \\
\hline Videned sinusoidal space & - & - & & & & & 1 \\
\hline 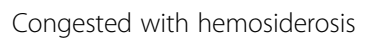 & - & - & & + & & & + \\
\hline lononuclear cellular infiltration & - & - & - & + & & + & + \\
\hline
\end{tabular}

Keys: ++ = severely present, $+=$ present, $-=$ absent, $A Q$ Aqueous, ET Ethanol, $C$ normal control 
Table 5 Histopathological result of rat's kidney administered aqueous and ethanolic extract of Spondias purpurea leaf

\begin{tabular}{|c|c|c|c|c|c|c|c|}
\hline Histopathological changes & $\mathrm{C}$ & $\begin{array}{l}\mathrm{AQ} \\
\text { ext } \\
\text { (m } \\
5,0 \\
15\end{array}$ & $\begin{array}{l}\text { tract } \\
\mathrm{g} / \mathrm{kg} \\
01,0 \\
00\end{array}$ & & & $\begin{array}{l}\text { extra } \\
\mathbf{g} / \mathbf{k g} \\
001,0 \\
00\end{array}$ & $\begin{array}{l}\text { ract } \\
\text { g) } \\
000\end{array}$ \\
\hline Congestion & - & + & + & + & + & ++ & + \\
\hline $\begin{array}{l}\text { Necrosis of renal } \\
\text { tubular epithelium }\end{array}$ & - & + & + & + & + & + & + \\
\hline Widened Bowman's space & - & + & + & + & + & + & + \\
\hline Collapsed renal tubules & - & - & - & - & - & - & + \\
\hline $\begin{array}{l}\text { Mononuclear } \\
\text { cellular infiltration }\end{array}$ & - & - & + & + & + & - & + \\
\hline $\begin{array}{l}\text { Congested with } \\
\text { Hemosiderosis }\end{array}$ & - & - & - & - & - & - & + \\
\hline $\begin{array}{l}\text { Adhesion of the parietal layer of the } \\
\text { glomerulus to the Bowman's space }\end{array}$ & - & - & + & + & - & + & + \\
\hline
\end{tabular}

Keys: ++ = severely present, $+=$ present, $-=$ absent, $A Q$ Aqueous, ET Ethanol, $C$ Normal control

significant $(p>0.05)$ changes when compared with the control group (Table 3).

\section{Histopathology studies}

Histopathological alterations were observed in the liver, kidney and spleen tissues of rats treated with aqueous and ethanol extracts of $S$. purpurea leaves at doses of 500,1000 and $1500 \mathrm{mg} / \mathrm{kg}$ bodyweight shown in Tables 4,5,6 and Figs. 1, 2, 3, 4, 5 and 6 . The features of liver tissue in the control group showed normal cellular architecture with distinct hepatic cells, sinusoidal space and a central vein (Fig. 1a). The kidney sections of the control group revealed normal glomerular basement membranes, normal cellularity and patent capsular space surrounding proximal and distal tubules (Fig. 2a). Spleen sections of control group were composed of capsule, trabeculae, white pulp (rich in lymphocyte), red pulp (antigen trapping and storage of red blood cells) (Fig. 3a).

\section{Discussion}

The safety in consumption of herbal products can be determined by a toxicity studies carried out using different experimental models to ascertain a safe dose margin for

Table 6 Histopathological result of rat's spleen administered aqueous and ethanolic extract of Spondias purpurea leaf

\begin{tabular}{llllllll}
\hline Histopathological changes & $\begin{array}{l}\text { C } \\
\text { AQ extract } \\
(\mathbf{m g} / \mathbf{k g})\end{array}$ & \multicolumn{3}{l}{$\begin{array}{l}\text { ET extract } \\
\text { kg) }\end{array}$} \\
& \multicolumn{2}{c}{$\mathbf{5 , 0 0 1 , 0 0 0}$} & $\mathbf{1 5 0 0}$ & $\mathbf{5 , 0 0 1 , 0 0 0}$ & 1500 \\
\hline Congestion & - & ++ & ++ & + & ++ & ++ & + \\
Lymphocyte proliferation & - & - & - & + & - & + & + \\
Congested with haemosiderosis & - & - & - & - & - & - & + \\
\hline
\end{tabular}

Keys: $++=$ severely present, $+=$ present, $-=$ absent, $A Q$ Aqueous, $E T$ Ethanol, $C$ Normal control human use. The bioactive components in plants and the dosages consumed affect their actions [19]. Their influence in the body fluid and tissues can be revealed through haematology and histopathology studies [4]. The acute toxicity study indicated that the extracts at a dose of $5000 \mathrm{mg} / \mathrm{kg}$ bodyweight was safe with no mortality recorded. According to OECD and Ecobichon [20], any compound that does not produce adverse effect at a dose of $5000 \mathrm{mg} / \mathrm{kg}$ body weight is considered nontoxic.

The blood profile generally provides important information on the response of the body to injuries, lesions, deficiency or stress [21]. Haematological analysis is carried out to evaluate the therapeutic usefulness of consumed foreign substances and its adverse effect in the body. The hematological analysis of rats treated with aqueous and ethanol extract of $S$. purpurea leaf at doses of 500,1000 and $1500 \mathrm{mg} / \mathrm{kg}$ showed no significant difference $(p>0.05)$ compared to the control group. This outcome suggests that the active components in the plant extract may have not repressed the synthesis of the blood cells. Haemoglobin $(\mathrm{Hb})$ has the ability to transport oxygen into the tissues and carbondioxide out of the body tissues and absorb nutrients used to release energy for body use [22]. The observed result suggests that the extracts may have not affect the process of erythropoiesis [4]. White blood cells (WBC), fights infections and inflammation in the body. Thus, the non-significant changes in WBCs may indicate that the extracts did not increase or suppression the immune response of treated animals [23]. The liver produces numerous proteins frequently found in the blood. There was an insignificant increase $(p>0.05)$ observed in total plasma proteins of rats administered aqueous and ethanol leaf extract of $S$. purpurea, which is an indication that the extracts had no substantial effect on plasma protein synthesis.

Histopathological studies of the liver, kidney and spleen are important for the vital roles they play in survival of animals [24]. Results of the histopathological examination showed that the daily administration of aqueous and ethanol extract of $S$. purpurea leaf in rats produced certain signs of damages in the tissues compared to the control group. These effects may be due to the frequency of administration or the dosage coupled with the presence of one or more of the chemical constituents present in the extract that may have acted as pro-oxidant.

Congestion in the liver is the accumulation of blood vessels resulting from either increased hepatic venous pressure or decreased hepatic blood flow. Sinusoids are low pressure vascular channels that receive and convey blood to the central veins. When the hepatic venous pressure is elevated either due to obstruction of the hepatic veins, vascular stasis or congestion, dilation of the sinusoidal space is initiated $[25,26]$. 


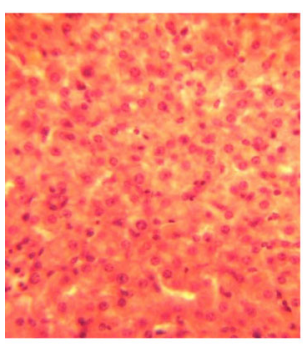

Plate Ia: Normal liver

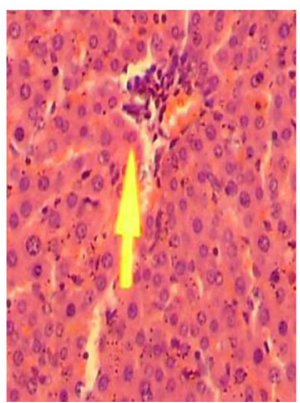

Plate Ic: Liver $(1000 \mathrm{mg} / \mathrm{kg})$ showing Mononuclear cellular infiltration

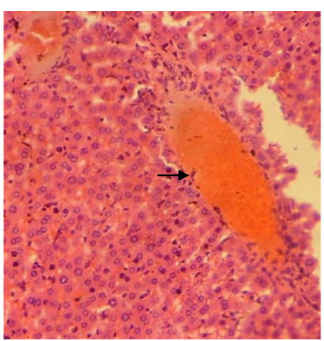

Plate Ib: Liver $(500 \mathrm{mg} / \mathrm{kg})$ showing congestion

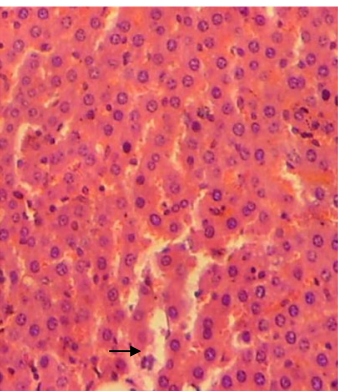

Plate Id: Liver $(1500 \mathrm{mg} / \mathrm{kg})$ showing widened sinusoidal space

Fig. 1 Photomicrograph of the liver of rats administered aqueous extract of Spondias purpurea leaf ( $\mathrm{H}$ and $\mathrm{E} \times 200)$. a Normal liver. $\mathbf{b}$ Liver (500 $\mathrm{mg} / \mathrm{kg}$ ) showing congestion. c Liver $(1000 \mathrm{mg} / \mathrm{kg}$ ) showing Mononuclear cellular infiltration. $\mathbf{d}$ Liver $(1500 \mathrm{mg} / \mathrm{kg})$ showing widened sinusoidal space

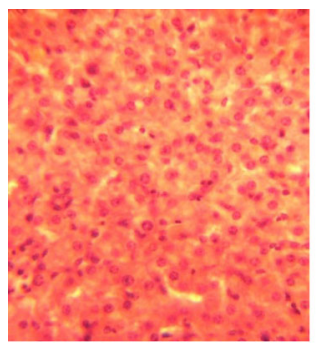

Plate IIa: Normal liver

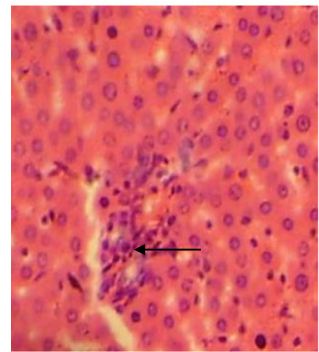

Plate IIc: Liver (1000 mg/kg) showing mononuclear cellular infiltration

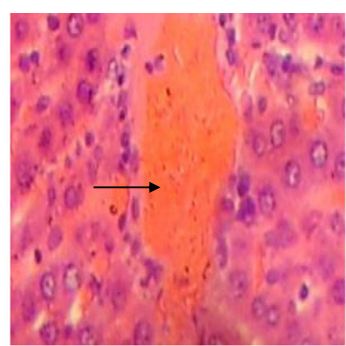

Plate IIb: Liver $(500 \mathrm{mg} / \mathrm{kg})$ showing congestion

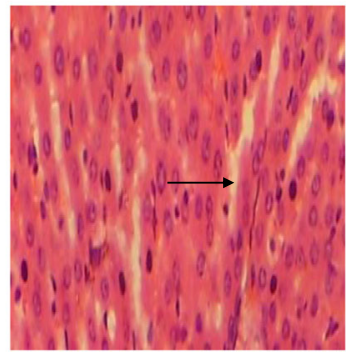

Plate IId: Liver $(1500 \mathrm{mg} / \mathrm{kg})$ showing widened sinusoidal space

Fig. 2 Photomicrograph of the liver of rats administered ethanol extract of Spondias purpurea leaf ( $\mathrm{H}$ and $\mathrm{E} \times 200)$. a Normal liver. b Liver (500 $\mathrm{mg} / \mathrm{kg})$ showing congestion. c Liver $(1000 \mathrm{mg} / \mathrm{kg})$ showing mononuclear cellular infiltration. $\mathbf{d}$ Liver $(1500 \mathrm{mg} / \mathrm{kg})$ showing widened sinusoidal space 


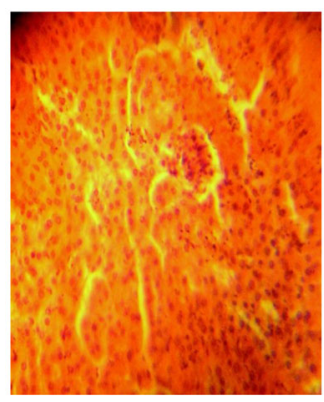

Plate IIIa: Normal kidney

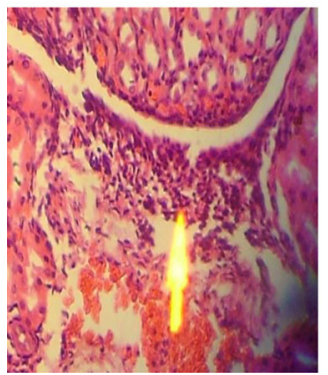

Plate IIIc: Kidney $(1000 \mathrm{mg} / \mathrm{kg})$ showing mononuclear cellular infiltration

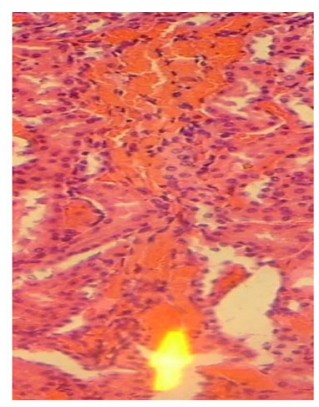

Plate IIIb: Kidney $(500$ mg/kg) showing inter-tubular congestion

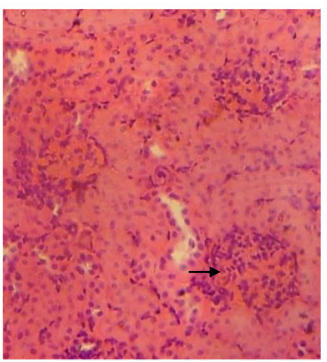

Plate IIId: Kidney $(1500 \mathrm{mg} / \mathrm{kg})$ showing adhesion of the parietal layer of glomerulus to the Bowman's space

Fig. 3 Photomicrograph of the kidney of rats administered aqueous extract of Spondias purpurea leaf ( $H$ and $E \times 200)$. a Normal kidney. b Kidney $(500 \mathrm{mg} / \mathrm{kg}$ ) showing inter-tubular congestion. c Kidney $(1000 \mathrm{mg} / \mathrm{kg}$ ) showing mononuclear cellular infiltration. d Kidney $(1500 \mathrm{mg} / \mathrm{kg}) \mathrm{showing}$ adhesion of the parietal layer of glomerulus to the Bowman's space

Haemosiderosis in the liver, spleen and kidney is an iron storage compound (haemosiderin), usually found in macrophages attributed to prolonged congestion of blood vessels leading to the release of iron and build-up within the organs. They are more prominent in young female adult rats than in the males [27].

Mononuclear cellular infiltration is an aggregate of lymphocytes, plasma cells and macrophages commonly affecting the liver and kidneys. They fight infections and adjust to intruders within tissues [28]. The kidney is vulnerable to injuries from several substances due to high rate of perfusion by the blood and its ability to concentrate substances in the tubular lumen [29]. The renal tubule contains cells that filters and cleans the blood, while the renal tubule epithelium is the outer layer of cells surrounding the renal tubule which functions in handling electrolytes, water and amino acids [30]. The aqueous and ethanol extract of $S$. purpurea leaf may have been perceived as a toxin by the kidney resulting in degenerative changes around the epithelium leading to the observed cell death [31]. Farber et al., [32], reported that extrinsic insult to the cells such as osmotic, thermal, toxic or traumatic effect could result into pathological and accidental cell death. The mononuclear cellular infiltration evident in the liver and kidney may have appeared to stop the spread of necrosis to other parts of the tissues.
Collapse renal tubules was only observed in the group administered the highest dose of ethanol extract of $S$. purpurea leaf $(1500 \mathrm{mg} / \mathrm{kg})$. Necrosis of the epithelium surrounding the renal tubules can lead to the disruption of the structural and functional integrity of the membrane. Hence, the greater the severity of the insult on the epithelium the more rapid the progression of the damage on the renal tubules and their subsequent failure [31].

The presence of one or more phytochemicals in the extracts or their synergistic effect may have resulted in adhesion of the parietal layer of the glomerulus to the Bowmans capsule observed at the doses of 1000 and $1500 \mathrm{mg} / \mathrm{kg}$ bodyweight of aqueous and ethanol extract of S. purpurea leaf. The repopulation of glomerular tuft by the parietal epithelial during focal segmental glomerulosclerosis is one of the reasons for the adhesion between glomerulus and the Bowmans capsule [32]. Podocytes are cells lining the capillaries of the glomerulus, injury to them results in their structural alterations and subsequent loss. Podocytopenia and drug toxicity are associated with glomerulosclerosis [33]. Lymphocytes are the principal cells of the immune system that contributes primarily in immune defences [34]. The aqueous extract of S. purpurea leaf at $1500 \mathrm{mg} / \mathrm{kg}$ and the ethanolic extract at 1000 and $1500 \mathrm{mg} / \mathrm{kg}$ bodyweight stimulated lymphocyte proliferation in the spleen, suggesting 


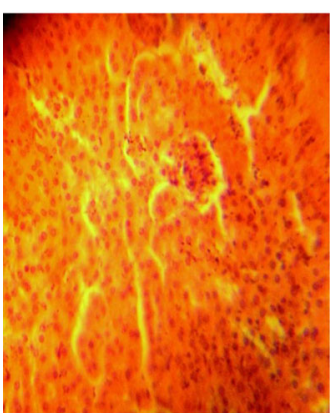

Plate IVa: Normal Kidney

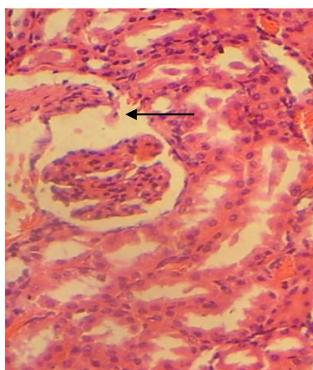

Plate IVc: Kidney $(1000 \mathrm{mg} / \mathrm{kg})$ showing widened Bowman's space

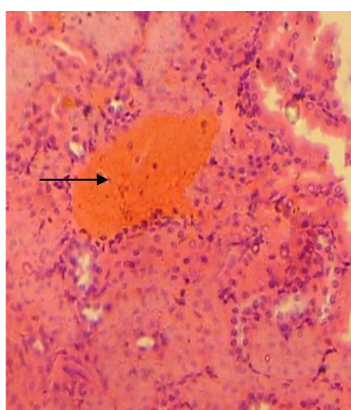

Plate IVb: Kidney $(500 \mathrm{mg} / \mathrm{kg}$ ) showing congestion

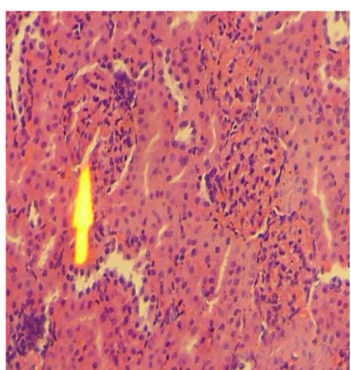

Plate IVd: Kidney $(1500 \mathrm{mg} / \mathrm{kg})$

showing adhesion of the parietal layer of glomerulus to the Bowman's space

Fig. 4 Photomicrograph of the kidney of rats administered ethanol extract of Spondias purpurea leaf ( $H$ and $E \times 200)$. a Normal Kidney. b Kidney $(500 \mathrm{mg} / \mathrm{kg})$ showing congestion. c Kidney $(1000 \mathrm{mg} / \mathrm{kg})$ showing widened Bowman's space. $\mathbf{d}$ Kidney $(1500 \mathrm{mg} / \mathrm{kg})$ showing adhesion of the parietal layer of glomerulus to the Bowman's space

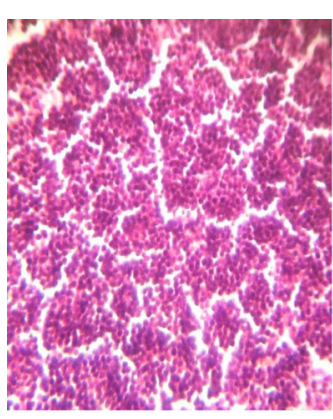

Plate Va: Normal Spleen

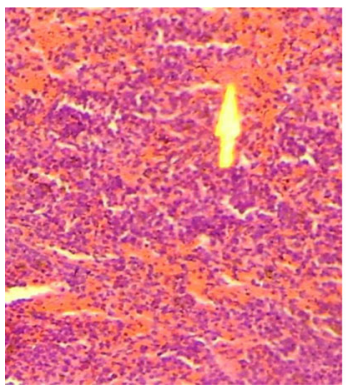

Plate Vc: Spleen section $(1000 \mathrm{mg} / \mathrm{kg})$ showing congestion

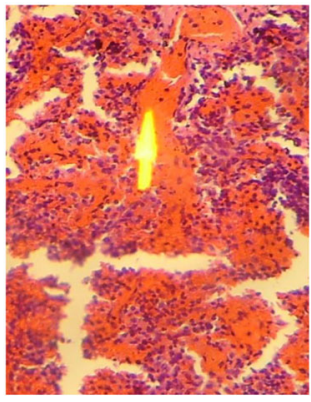

Plate Vb: Spleen $(500 \mathrm{mg} / \mathrm{kg})$ showing congestion

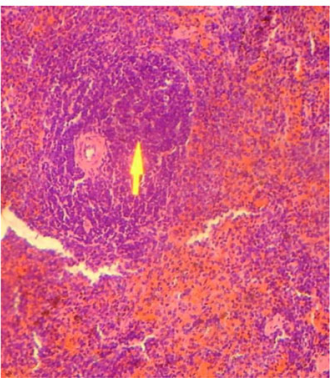

Plate Vd: Spleen section $(1500 \mathrm{mg} / \mathrm{kg})$ showing Lymphocyte proliferations

Fig. 5 Photomicrograph of the spleen of rats administered aqueous extract of Spondias purpurea leaf ( $H$ and $E \times 200)$. a Normal Spleen. b Spleen $(500 \mathrm{mg} / \mathrm{kg})$ showing congestion. c Spleen section $(1000 \mathrm{mg} / \mathrm{kg})$ showing congestion. d Spleen section $(1500 \mathrm{mg} / \mathrm{kg})$ showing Lymphocyte proliferations 

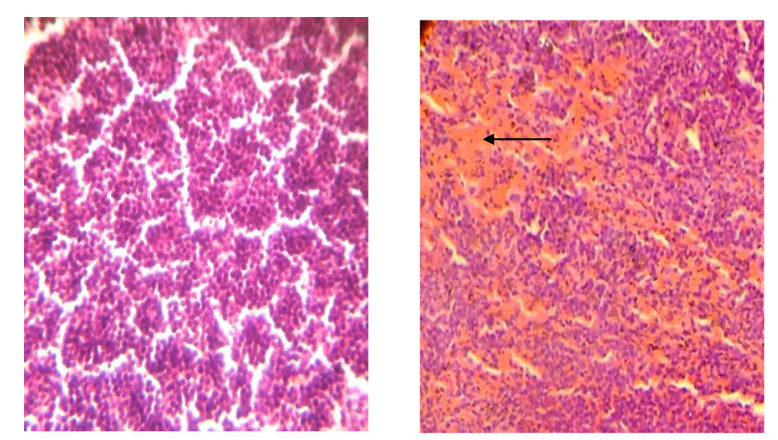

Plate VIa: Normal Spleen

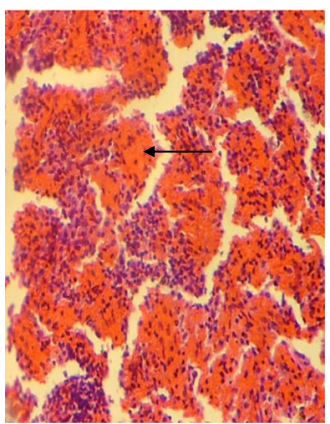

Plate VIb: Spleen $(1000 \mathrm{mg} / \mathrm{kg})$ showing congestion
Plate VIb: Spleen $(500 \mathrm{mg} / \mathrm{kg})$ showing congestion

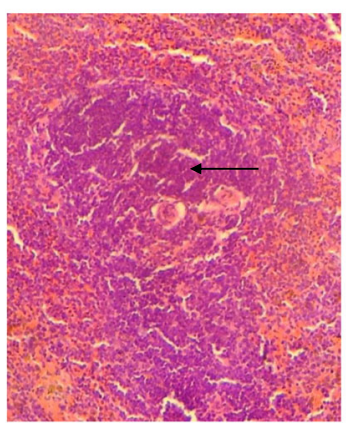

Plate VId: Spleen $(1500 \mathrm{mg} / \mathrm{kg})$ showing lymphocyte proliferations

Fig. 6 Photomicrograph of the spleen of rats administered ethanol extract of Spondias purpurea leaf $(\mathrm{H}$ and $\mathrm{E} \times 200)$. a Normal Spleen. b Spleen $(500 \mathrm{mg} / \mathrm{kg})$ showing congestion. c Spleen $(1000 \mathrm{mg} / \mathrm{kg})$ showing congestion. d Spleen $(1500 \mathrm{mg} / \mathrm{kg})$ showing lymphocyte proliferations

that the extracts contains agents that may have the ability to stimulate the production of lymphocytes at higher doses thus boost the immune system and may explains the non-significant increase in lymphocyte count from Tables 1 and 2. Lymphocytes are reported to respond to antigen challenge by proliferating and producing lymphokines therefore strengthening the immune response [35].

\section{Conclusion}

The result obtained from the haematological analysis indicated that the extract had no significant effect on the overall blood parameters. However, the aqueous and ethanol extracts of Spondias purpurea leaf at the doses of 1000 and $1500 \mathrm{mg} / \mathrm{kg}$ body weight altered the integrity of the liver, kidney and spleen of the rats which may become significant after prolonged consumption.

\section{Acknowledgements}

Not applicable.

\section{Authors' contributions}

All authors contributed equally. All authors read and approved the final manuscript.

Funding

None.

Availability of data and materials

Not applicable.

\section{Declarations}

\section{Ethics approval and consent to participate}

The study protocol was approved by the Ethical Committee of the Federal University Technology, Minna Nigeria and assigned number: 000017EAU.

\section{Consent for publication}

Not applicable.

\section{Competing interests}

The authors declare that they have no competing interests.

\section{Author details}

'Department of Biochemistry, Federal University of Technology, Minna, Nigeria. ${ }^{2}$ Department of Biological Sciences, Ibrahim Badamasi Babangida University, Lapai, Nigeria.

Received: 25 May 2021 Accepted: 21 November 2021

Published online: 26 November 2021

\section{References}

1. Olayode OA, Daniyan MO, Olayinwola G. Biochemical, hematological and histopathological evaluation of the toxicity potential of the leaf extract of Stachytarpheta cayennensis in rats. J Trad Compl Med. 2019;10(6):544-54.

2. Koparde AA, Doijad RC, Magdum CS. Natural products in drug discovery. In: Pharmacognosy-medicinal plants, IntechOpen; 2019. p. 1-2.

3. Bautista P, Gonzalez-Lopez L, Gonzalez-Esparza B, Castillo-Rosas C. Effects of bioactive nutriments in health and disease: the role of epigenetic modifications. IntechOpen. 2017. p. 124. https://doi.org/10.5772/intechopen. 68789.

4. Amah AK, Makena W, Ezekwe AS, Ejiofor DC, Nwanegwo C, Ewa O. Haematological evaluation of aqueous and methanolic leaf extracts of Thaumatococcus daniellii and Alchornea cordifolia in wistar rats. GSC Biol Pharm Sci. 2019;08(01):123-7.

5. Salma S, Eman A, Rola M, Labib A, Nasser S. Genus Spondias: a phytochemical and pharmacological review. Evid-Based Complementary Altern Med. 2018:5382904:13. https://doi.org/10.1155/2018/5382904

6. Taiwo OE, Tomayo LS. GC-MS analysis and antioxidant activity of Spondias purpurea L (Anacardiaceae). Pharmacogn J. 2018;10(5):941-5.

7. Engels C, Gräter D, Esquivel P, Jiménez VM, Gänzle MG, Schieber A. Characterization of phenolic compounds in jocote (Spondias purpurea L.) peels by ultra-high-performance liquid chromatography/electrospray ionization mass spectrometry. Food Res Int. 2012;46(2):557-62.

8. Rosas-Piñón Y, Mejía A, Díaz-Ruiz G, Aguilar MI, Sánchez-Nieto S, Rivero-Cruz JF. Ethnobotanical survey and antibacterial activity of plants used in the Altiplane region of Mexico for the treatment of oral cavity infections. J Ethnopharmacol. 2012;141(3):860-5.

9. Muñiz A, Garcia E, Gonzalez D, Zuñiga L. Antioxidant Activity and In Vitro Antiglycation of the Fruit of Spondias purpurea. Evid-Based Complementary Altern Med. 2018;5613704:7.

10. Ferreira-de-Almeida CL, Alves-Brito S, Italo-de-Santana T, Alves-Costa HB, Reis-de-Carvalho Júnior CH, Vanusa-da-Silva M, et al. Spondias purpurea L. (Anacardiaceae): Antioxidant and Antiulcer Activities of the Leaf Hexane Extract. Oxid Med Cell Longev. 2017;6593073:14. https://doi.org/10.1155/201 7/6593073.

11. Wright GD. Unlocking the potential of natural products in drug discovery. Microb Biotechnol. 2018;12(1):55-7.

12. Orhue ES, Idu M, Ataman JE, Ebite LE. Haematological and Histopathological studies of Jatropha tanjorensis (J.L. Ellis and Soroja) leaves in rabbits. Asian J Biol Sci. 2008;1:84-9.

13. Oyewole IO, Magaji ZJ, Awoyinka OA. Biochemical and toxicological studies of aqueous extract of Tethonia diversifolia (Hemsl.) leaves in wistar albino rats. J Med Plant Res. 2007;1:30-3.

14. Atangwho IJ, Ibeneme CE, Egbung GE, Ibeneme E, Eno MA, Nwankpa P. Effect of long-term feeding of the Obudu natural honey and table sugar- 
sweetened diets on obesity and pro-inflammatory biomarkers in rats. BMC Nutr. 2020;6:3. https://doi.org/10.1186/s40795-019-0327-2.

15. Lorke D. A new approach to practical acute toxicity testing. Arch Toxicol. 1983:54:275-87.

16. Al-Afifi NA, Alabsi AM, Bakri MM, et al. Acute and sub-acute oral toxicity of Dracaena cinnabari resin methanol extract in rats. BMC Complement Altern Med. 2018;18:50.

17. Lowry OH, Rosebrough NJ, Farr AL, Randall RJ. Protein measurement with the Folinphenol reagent. J Biol Chem. 1951;193:265-7.

18. Aliyu R, Adebayo AH, Gatsing D, Garba H. The effect of ethanolic leaf extract of Commiphora Africana (Burseraceae) on rat's liver and kidney functions. J Pharmacol Toxicol. 2007;2(4):373-9.

19. Gololo SS. Potential adverse effects of alteration of phytochemical accumulation in fruits and vegetables. London: IntechOpen; 2018. https:// doi.org/10.5772/intechopen.77099.

20. Ecobichon DJ. Acute toxicity studies. In: Hollinger MA, editor. The basic of toxicity testing. Baca Ration: CRC Press; 1995. p. 35-8.

21. Bosco AD, Gerencser Z, Szendro Z, Mugnai C, Cullere M, Kovacs M, et al. Dietary supplementation of spirulina (Arthrospiraplatensis) and Thyme (Thymus vulgaris) on rabbit meat appearance, oxidative stability and fatty acid profile during retail display. Meat Sci. 2014;96:114-9.

22. Enechi OC, Amah CC, Okagu IU, Ononiwu CP, Azidiegwu VC, Ugwuoke EO, et al. Methanolic extract of Fagara zanthoxyloides leaves possess antimalarial effects and normalizes haematological and biochemical status of plasmodium berghei-passaged mice. Pharm Biol. 2019;57(1):577-85.

23. Tousson E, El-Moghazy M, El-Atrsh E. The possible effect of diets containing Nigella sativa and Thymus vulgaris on blood parameters and some organs structure in rabbit. Toxicol Health. 2011;27:107-16.

24. Ali MD, Naseer MA, Mirza MA, Alam AZ. Haematological, biochemical, and histopathological study of the plant extract of Terminalia chebula Reitz., Aleo vera Linn., and Tamarindus indica Linn on animal model: a comparative study. Natl J Physiol Pharm Pharmacol. 2019;9(3):268-75.

25. Brancatelli G, Furlan A, Dioguardi-Burgio M. Hepatic sinusoidal dilatation. Abdom Radiol. 2018;43(8):2011-22.

26. Hilscher M, Sanchez W. Congestive hepatopathy. Clin Liver Dis. 2016;8(3):68-71.

27. Boes KM, Durham AC. Bone marrow, blood cells and the lymphoid/ lymphatic system. Pathol Basis Vert Dis. 2017;724-804.e2. https://doi.org/10.1 016/B978-0-323-35775-3.00013.8.

28. Patrick DJ, Rebelatto MC. Toxicological pathology and background lesions of nonhuman primates. In: Bluemel J, Korte S, Schenck E, et al., editors. The nonhuman primate in nonclinical drug development and safety assessment. Cambridge: Academic press; 2015. p. 235-56.

29. Kebede A, Kemal J, Alemayehu H, Mariam H. "Isolation, identification and antibiotic susceptibility testing of Salmonella from slaughtered bovines and ovines in Addis Ababa abattoir enterprise, Ethiopia: a cross-sectional study". Intl. J Bacteriol. 2016;3714785:8.

30. Ronco C, Chawla LS. Glomerular filtration rate, renal functional reserve and kidney stress testing. In: Ronco C, Bellomo R, Kellum A, et al., editors. Critical care nephrology ( $3^{\text {rd }}$ edition). Amsterdam: Elsevier; 2019. p. 48-59.

31. Eweka AO. Histological studies of the effects of oral administration of Aspilia africana (Asteraceae) leaf extract on the ovaries of female wistar rats. Afri 」 Trad, Complemetary Altern Med. 2008;6(1):57-61.

32. Farber $\mathrm{J}$, Chein $\mathrm{KR}$, Mittnacht $\mathrm{S}$. The pathogenesis of irreversible cell injury in ischemia. Am J Pathol. 1981;102:271-81.

33. Fenton RA, Praetorius J. Anatomy of the kidney. In: Skorecki K, Taal MW, editors. Brenner and Rector's the kidney. Philadelphia: Elsevier; 2016. p. 42-82.

34. Kim JS, Han BG, Choi SO, Cha S. Secondary focal segmental glomerulosclerosis: From podocyte injury to glomerulosclerosis. BioMed Res Intl. 2016;1630365:7.

35. Gomez-Flores R, Verastegui-Rodriguez L, Quintanilla-Licea R, Tamez-Guerra P, Tamez-Guerra R, Rodriguez-Padilla C. Invitro rat lymphocyte proliferation induced by Ocinum basilicm, Persea Americana, Plantago virginica and Rosa spp. Extracts. J Med Plants Res. 2008;2(1):005-10.

\section{Publisher's Note}

Springer Nature remains neutral with regard to jurisdictional claims in published maps and institutional affiliations.

\section{Submit your manuscript to a SpringerOpen ${ }^{\circ}$ journal and benefit from:}

- Convenient online submission

- Rigorous peer review

- Open access: articles freely available online

- High visibility within the field

- Retaining the copyright to your article

Submit your next manuscript at $\boldsymbol{\nabla}$ springeropen.com 